Pena Justisia: Media Komunikasi dan Kajian Hukum

Vol. 17 No. 2, 2017, 53-58

Artikel Hasil Penelitian

\title{
The Attendance of Independent Candidates in Local Head Election as a Effort to Improvement The Government System
}

\author{
*1Joko Martono, ${ }^{\text {B Budimansyah, }}{ }^{3}$ Annurdi \\ 123 Faculty of Law, Panca Bhakti University, Indonesia
}

Artikel Diterima:

27 Oktober 2017

Artikel Disetujui:

16 November 2017

Artikel Diterbitkan:

15 Desember 2017

Korespondensi Penulis: jokomartono390@gmail.com

\begin{abstract}
The nature of political party is accentuate their interest that causes the decrease of public confidence in political party. It affects to the election of local heads, when the candidat supported by political party in the election process. So that the presence of regulation that opens the opportunity for independent candidates in the election of local head, raises the hope to improve the government system. This research type is normative juridical research, and the data used for this research are some legislations, documents and books relating the election of local head. The result of this research revealed that independent candidates that elected as local head face prolem when they must be able to maintain a balance with the local parlemen as a consequence of did not get support from political parties.
\end{abstract}

Keywords: Independent Candidat, Local Head Election

\section{Abstrak}

Karakteristik partai politik yang memiliki kecenderungan menonjolkan kepentngan mereka berdampak turunnya kepercayaan masyarakat terhadap partai politik. Hal tersebut berpengaruh pada pemilihan kepala daerah, saat calon yang didukung oleh partai politik dalam proses pemilihan kepala daerah, sehingga hadirnya peraturan yang membuka peluang bagi calon independen dalam pemilihan kepala daerah, menimbulkan harapan untuk memperbaiki sistem pemerintahan. Jenis penelitian ini adalah penelitian yuridis normatif, dan data yang digunakan untuk penelitian ini berupa peraturan, dokumen dan buku yang berkaitan dengan pemilihan kepala daerah. Hasil penelitian ini mengungkapkan bahwa calon independen yang terpilih sebagai kepala daerah menghadapi tantangan ketika harus mampu menjaga keseimbangan dengan DPRD, sebagai konsekuensi tidak mendapat dukungan dari partai politik pada saat pencalonan.

Kata Kunci : Calon Kepala Daerah Independen. 


\section{INTRODUCTION}

Theories about the state are known to be elements of the state, among others people, territory, government and recognition from other countries. The state according to Krasner is a number of roles and institutions that have special drives and goals that are different from the interests of any particular group in society. Based on this understanding can be seen that a country has a purpose, where the presence of the role of government as one element of the state as well as driving the wheels of government within a country is very important to realize the purpose of the country.

Furthermore, the purpose of government is distinguished by Aristotle into two :

1. a government which aims to shape the good, the general welfare, and the fulfillment of the public interest (a good cause); or

2. a government that aims to shape the good, the welfare, and the fulfillment of the interests of the holder of power itself (bad goals, deviations). ${ }^{1}$

The government's goal of Aristotle's interpretation as described above shows that the government as the holder of power in a country other than to realize the welfare of the people, but it is also possible to use his power to professionally. There is awareness of this, encouraging the people to strengthen the democratic system in Indonesia to give sovereignty to the people through direct electoral system by the people including direct election of regional heads.

Cecep Effendi, emphasized that there are four objectives in the direct election of the Regional Head. Namely, the election of regional heads can restore the right of the people to directly determine their leaders, create aspirational leaders, create political stability in the regions, and eliminate money politics practices (money politics). The direct election of regional heads as a process of learning and democracy at the local level should coincide with the overthrow of regional autonomy policies. Strictly speaking, with direct election of regional heads, regional autonomy must be maximal. So the results can be enjoyed by the people, because the direct election of the Head of Region is the entrance to the creation of democracy with the empowerment of all the potential of society, the unity of various elements of individuals in this society is expected to accelerate the creation of equity or justice in all aspects of community life. ${ }^{2}$

The direct electoral system by the people in Indonesia is currently applicable in the election of regional heads, with the hope that the elected regional head can prosper the people. On the other hand, in the process of nominating the regional head, a candidate for the regional head to participate in the election is required to obtain support from a political party. So the concern arises from the people that when the head of the region is elected will be interfered by the interests of the political parties that support it. On the basis of this idea then comes the idea of a candidate for independent regional head.

The presence of Act No. 8 on 2015 about the Election of Governors, Regents and Mayors, seems to provide an answer to the concerns of the people, which with this regulation provides an opportunity for independent candidates to participate in the election process without having to get support from political parties. At the same time, as an effort to avoid transactional politics between regional heads and political parties, so the presence of the regional head can be one of the efforts in improving the governance system in Indonesia.

Based on the description above, the writer was interested in conducting research in the form of a scientific paper titled "Attendance of Independent Candidates In Local Head Election As A Effort To Improvement The Government System".

\section{PROBELEM}

The problem in this research is how is the role of independent regional head as an effort to improve the governance system in Indonesia? 


\section{RESEARCH METHOD}

Tipe This study is normative, because it uses secondary data, or often called the research literature. Normative legal research is legal research laying down the law as a system of building norms. Norm system in question is about the principles, norms, rules of legislation, court decisions, agreements and doctrines. ${ }^{3}$ Secondary data used in this study include legislation relating to the election of local head, documents and writings relating to the cases studied.

Methods of data analysis used in this research is descriptive qualitative, meaning authors will present and explain the data obtained from the study of literature, which is manifested in a logical and systematic description. Once the ingredients necessary legal collected, the next step was made an analysis to clarify the settlement of the problem, then the conclusions drawn deductively, from things that are common to the things that are special. At this stage the legal material worked on and utilized in such a way to successfully conclude the truth of which can be used to address the issues raised in the study.

\section{DISCUSSION}

Awareness of the danger if power is not limited / absolutism is the original motive that led to the concept of people's sovereignty. If power is not restricted, there must be violation of rights, abuse of power and destruction of the state. ${ }^{4}$ Therefore, the essence of the 1945 Constitution as the constitution of the state is basically protecting and guaranteeing the rights of citizens to become the sovereign authorities of this country. One of the objectives of reform is to create a new Indonesia, a more democratic Indonesia, one of which is reflected by the direct election of regional heads by the people so as to create a democratic government.

The government based on the principle of democracy is a government whose leaders come from the people, by the people, and for the people.

Mukti Fajar Nur Dewata dan Yulianto Achmad, 2010, Dualisme Penelitian Hukum Normatif \& Empiris, Pustaka Pelajar, Yogyakarta, P. 34
Thus, the people (population) determine the organizers (leaders, the few). However, such democracy is almost impossible to obtain; Which appear before the eyes are few (few) people determine or control the crowds. ${ }^{5}$ The opinion of Robert Dahl in Miriam Budiardjo put forward five criteria of democracy as a political idea and how a government is called democratic : First, the running of state sustu government is based on law enforced, such as constitution, human rights, law, and free and impartial court; Second, the running of governance is under the real control of society. Here high political participation of society is needed; Third, the free, regular elections (elections), and allowing the majority of the population to vote and be elected; Fourth, the existence of majority principle, namely the adoption of consensus decision, if in the election is not achieved with the most votes; Fifth, the existence of guarantees for the democratic rights of civil society in the fields of politics, economy, social, and culture.

Earlier in the election of regional heads in Indonesia required the requirement that every candidate for regional head should receive support from a political party or a coalition of political parties. However, with the issuance of Decision of the Constitutional Court Number 5 / PUU-V / 2007, other than being submitted by a political party or a coalition of political parties, candidates for regional heads may be submitted through independent channels. One of the factors driving the cause of the provision of independent candidates is the desire of the community to elect the head of the region without having to go through a political party. This happens because of the view that political parties are currently unable to assume the aspirations of the people. Often the wishes and desires of the people are just opposite to what is done by political parties.

Opening an opportunity for everyone to become head of the region without having to get support from this politi party, does not mean also without any requirement. Pairs of independent

4 Jimly Asshiddiqie, 2007, Pokok-Pokok Hukum Tata Negara Indonesia Pasca Reformasi, PT. Bhuana Ilmu Populer, Jakarta, P. 145.

5 Jaih Mubarok, Op.Cit, P. 48. 
candidates can register as a candidate pair of Regent and Vice Regent or Mayor and Deputy Mayor if eligible support in accordance with the provisions As set forth in Law No. 8 of 2015. The terms of such support are as follows: (1) A district with a population of up to 250,000 (two hundred and fifty thousand) souls shall be supported at least 10\% (ten percent); (2) Regions / cities with a population of more than 250,000 (two hundred and fifty thousand) up to 500,000 (five hundred thousand) souls shall be supported at least $8.5 \%$ (eight point five percent). (3) A district with a population of more than 500,000 (five hundred thousand) up to $1,000,000$ (one million) souls shall be supported at least 7.5\% (seven point five percent). (4) A district with a population of more than $1,000,000$ (one million) souls shall be supported by at least $6.5 \%$ (six point five percent); (5) The amount of support referred to in letter $\mathrm{a}$, letter $\mathrm{b}$, letter $\mathrm{c}$, and letter $d$ shall be distributed in more than $50 \%$ (fifty percent) of the subdistrict in the said Regency / City.

Whereas individual Candidate can register as Candidate of Governor and Candidate of Vice Governor if eligible to support with the following provisions : (1) Provinces with a population of up to 2,000,000 (two million) souls shall be supported at least $10 \%$ (ten per cent); (2) Provinces with population of more than 2,000,000 (two million) souls up to $6,000,000$ (six million) souls shall be supported at least $8.5 \%$ (eight and a half percent); (3) Provinces with population of more than $6,000,000$ (six million) souls up to $12,000,000$ (twelve million) souls shall be supported at least 7.5\% (seven and a half percent); (4) Provinces with a population of more than 12,000,000 (twelve million) souls shall be supported at least $6.5 \%$ (six and a half percent); and (5) The amount of support referred to in letter $a$, letter $b$, letter $c$ and letter $d$ shall be distributed in more than 50\% (fifty percent) of the number of districts / cities in the said Province.

Joko P. Prihatmoko. 2008. Mendemokrasikan Pemilu: Dari Sistem Sampai Elemn Teknis: Yogyakarta: Pustaka Pelajar, P. 284.
Certainly the presence of independent candidates will have an impact on the implementation of the state, especially in the political sector. However, based on a survey conducted by Kompas, $67.2 \%$ of the public said they were not worried that the non-party path would erode the existence of political institutions as the main pillar of democracy. Quite the contrary based on a survey conducted by Kompas, $70.3 \%$ of the opinion that the presence of individual candidates will actually encourage the party to be more selective in nominating the head of the region. Even as many as $73.6 \%$ of the public actually sees competition between individual candidates and political parties will provide many options and opportunities for the public to get the best regional head.

Everything should be have the advantages and disadvantages, as well as opportunities for independent candidates. The disadventages of independent paths among others: 6

1. However the party remains the main pillar of representative democracy (representative democracy). The Party is designed to play a role in any public policy making including leadership recruitment.

2. The less democratic situation is too great burden and the consequences for independent candidates to bear. The moral and financial burden on which independent candidates must spend many cost the elections, such as for campaign and other operational expenses.

The obstacles that faced by independent candidates as described above lead to low interest to move forward as regional heads through independent channels. Based on a study conducted by the Indonesian Survey Scale (SSI) on the results of elections in 2015, it shows that independent candidates who advanced in elections 2015 new by 35 percent. Of these, the only record of 14.4 percent. Based on the survey, it can be concluded that to date both the interest and the chances of winning the candidates for regional heads are still low. On the island of Java, the win rate of independent 
candidates was 11.1 percent. While outside of Java, the level of winning independent candidates by 15.3 percent. The greatest winning candidate candidate is in NTT (33.3 percent) and on Borneo Island (22.2 percent). While in NTB and Maluku Islands, no independent candidate can win the contestation. ${ }^{7}$

In addition, the candidate for regional heads through by independent, winning line in the regional head election still faces the challenge of maintaining a balance in government with the existing political parties in parliament, as independent regional heads will find it difficult to enter into the local government process without got support from political parties.

\section{CONCLUSION}

The opportunity to move forward as head of the region through an independent channel gives hope to the community in improving the system of government, as it is considered to avoid the occurrence of transactional politics. However, there are still some obstacles that must be faced by independent candidates in the election process of the regional head, and if elected the independent regional head is also experiencing problems in maintaining balance with the local parliament in local government.

\section{REFERENCE}

Abdullah, H. Rozali. 2005. Pelaksanaan Otonomi Luas Dengan Pemilihan Kepala Daerah Secara Langsung. Jakarta: PT Raja Grafindo Persada.

Asshiddiqie, Jimly. 2007. Pokok-Pokok Hukum Tata Negara Indonesia Pasca Reformasi. Jakarta: PT. Bhuana Ilmu Populer;

Dewata, Mukti Fajar Nur \& Achmad, Yulianto. 2010. Dualisme Penelitian Hukum Normatif \& Empiris. Yogyakarta: Pustaka Pelajar;

Mubarok, Jaih \& Siyasah, Fiqh. 2005. Study tentang Ijtihad dan Fatwa Politik di Indonesia. Bandung: Pustaka Quraisy.
Prihatmoko, Joko P. 2008. Mendemokrasikan Pemilu: Dari Sistem Sampai Elemn Teknis Yogyakarta: Pustaka Pelajar;

"Calon Independen Masih Sulit Menang”. Available online: http://www.republika.co.id/berita/koran /teraju/16/03/22/o4fqgs6-calonindependen-masih-sulit-menang

7 Calon Independen Masih Sulit Menang". Available on: http://www.republika.co.id/berita/koran/teraju/16/03/ 22/o4fqgs6-calon-independen-masih-sulit-menang 